Original article

\title{
Relationship between fatty acid composition and softness score of adipose tissue in intensively reared lambs fed with concentrate based on cereals or on beet pulp
}

\author{
Jérôme NORMAND ${ }^{\mathrm{a}}$, Pierre BAS ${ }^{\mathrm{b} *}$, Valérie BERTHELOT ${ }^{\mathrm{b}}$, \\ Daniel SAUVANT ${ }^{\mathrm{b}}$ \\ a Institut de l'Élevage, Service Viande, ACTIPOLE, 5 rue Hermann Frenkel, \\ 69364 Lyon Cedex 07, France \\ b UMR Physiologie de la Nutrition et Alimentation INRA-INA P-G, 16 rue Claude-Bernard, \\ 75231 Paris Cedex 05, France
}

(Received 6 July 2004; accepted 3 February 2005)

\begin{abstract}
The aim of the study was to investigate the effect of substituting cereals by sugar beet pulp in the feed on the fatty acid (FA) composition of subcutaneous adipose tissue in indoor lambs. Forty-nine male lambs of the Lacaune dairy breed were fed from $23.6( \pm 4.1)$ to $41.0( \pm 1.9) \mathrm{kg}$ live weight with hay and a pelleted concentrate containing either $80 \%$ of barley and wheat (group C) or $70 \%$ sugar beet pulp (group P). The FA composition of caudal adipose tissue sampled at slaughter was determined. The subcutaneous adipose tissue softness was not different between the two groups. The water content and the proportion of odd-numbered (oddFA) and methyl branched-chain FA (BCFA) were high but not significantly different between the two groups (respectively, $22.6 \%$ of wet weight, 7.7 and $9.7 \%$ of total FA). On the contrary, the proportion of even-numbered saturated FA (ESFA) and especially $\mathrm{C}_{18: 0}$ was low but slightly higher in the $\mathrm{P}$ group. The proportions of $\mathrm{C}_{18.2}$ and $\mathrm{C}_{18: 3}$ were higher in group $\mathrm{C}$ than in group $\mathrm{P}(3.2$ vs. $2.2 \%, P<0.001$ and 0.65 vs. $0.48 \%$, $P<0.001$, respectively). The softness score of adipose tissue was positively related to the water content and proportion of oddFA and BCFA. It was negatively related to the proportion of ESFA, age and live weight at the beginning of the trial. The proportion of unsaturated FA with 18 atoms of carbon did not show any relationship with the adipose tissue softness but it was influenced to some extent by the composition of the diet.
\end{abstract}

lamb / sugar beet pulp / adipose tissue / fatty acid / softness index

Résumé - Effet de la nature de l'énergie ingérée, céréales vs. pulpes de betteraves, sur la composition en acides gras du tissu adipeux caudal d'agneaux de bergerie. L'objectif de ce travail était de mesurer l'incidence de la distribution de pulpes de betteraves en remplacement des graines de céréales dans le régime alimentaire d'agneaux de bergerie sur la composition en acides gras (AG) du tissu adipeux de couverture. Au total, 49 agneaux mâles, de race Lacaune « lait » ont

* Corresponding author: bas@inapg.inra.fr 
été engraissés de 23,6 ( $\pm 4,1)$ à 41,0 ( $\pm 1,9) \mathrm{kg}$. Ils disposaient en libre accès de foin et d'un aliment concentré aggloméré composé de $80 \%$ d'orge et de blé (lot $\mathrm{C}$ ) ou de $70 \%$ de pulpe de betterave (lot P). La composition en AG d'un échantillon de tissu adipeux caudal prélevé sur chaque animal lors de l'abattage a été déterminée. L'index de fermeté ne diffère pas significativement entre les 2 groupes. La teneur en eau et la proportion des AG à chaîne carbonée impaire ou ramifiée ont été élevées et non significativement différentes (respectivement, 22,6\% du poids frais, 7,7 et 9,7\% des $\mathrm{AG}$ totaux). Inversement, les teneurs en AG saturés pairs et notamment en $\mathrm{C}_{18: 0}$ ont été faibles. Les teneurs en $\mathrm{C}_{18.2}$ et $\mathrm{C}_{18.3}$ ont été plus élevées dans le lot $\mathrm{C}$ que dans le lot $\mathrm{P}(3,2$ vs. $2,2 \%, P<0,001$ et 0,65 vs. $0,48 \%, P<0,001$, respectivement). La note de fermeté des gras est liée positivement aux teneurs en eau et en AG à chaîne carbonée impaire ou ramifiée et négativement aux teneurs en AG gras saturés pairs, au poids vif et à l'âge en début d'essai. Les teneurs en AG insaturés à 18 atomes de carbone ont été indépendantes de l'index de fermeté des gras de couverture mais liées à la nature de la ration.

agneau / pulpes de betteraves / tissu adipeux / acide gras / fermeté

\section{INTRODUCTION}

In order to face competition of foreign lamb meat, regional and national labels are being developed in France to help place French products on high quality trade markets. For these labels, specifications are required on the lamb origin, diets and also on weight, conformation, fatness and fat quality of carcasses. In non-label markets, the fat quality often has consequences in a competitive market of lamb carcasses. Therefore, carcasses having soft or light cream to brown-red coloured adipose tissue are excluded from these markets and could result in important financial losses.

Diets rich in cereals, often used for fattening of indoor lambs, may be responsible for the occurrence of fat softness problems as pointed out by several authors $[16,17$, 37]. The fermentation of these diets in the rumen may lead to high quantities of propionate, the main substrate for gluconeogenesis. When in excess, propionate might also be either used as a precursor for the synthesis of odd-numbered fatty acids (oddFA) or metabolised into methylmalonate, which is a precursor of methyl branched-chain fatty acids (BCFA) $[19,41]$. The proportions of these low melting point $F A$ are high in soft adipose tissues $[9,12,16]$. The substitution of cereals by other feedstuffs able to modify the fermentation pattern without decreasing the lamb growth rate has been studied by several researchers. In some tri- als, cereals were substituted by sugar beet pulp in ovine and bovine growing animals [26, 33, 34, 42, 44]. In these trials beet pulp induced higher quantity [42] or proportion [44] of acetic acid in the rumen. In one trial [26], the effect of substituting cereals by beet pulp did improve the softness of adipose tissue but had no beneficial effects in the two others $[33,42]$. In these studies, fat softness was scored by visual and tactile judgement. Whereas it is well known that softness of adipose tissues is linked to an alteration of its fatty acid profile, there are, to our knowledge, no studies of beet pulp incorporation in the diet on the fatty acid composition of adipose tissues of lambs.

The aim of the present paper was first, to study the relationships between the fatty acid proportions and the indexes of softness of lamb subcutaneous adipose tissue, and to improve our understanding of the effects of lamb performance on the variations in the composition of fatty acid of adipose tissue. Secondly, the effects of substituting cereals by sugar beet pulp were compared on fatty acid composition of adipose tissue.

\section{MATERIALS AND METHODS}

\subsection{Animals and treatments}

Forty-nine male lambs of the Lacaune Dairy breed, sired from 8 rams, were suckled until 4 weeks of age and then were abruptly 
Table I. Composition and nutritional values of the experimental concentrates.

\begin{tabular}{|c|c|c|}
\hline & Cereal & Beet pulp \\
\hline \multicolumn{3}{|l|}{ Composition (\% DM) } \\
\hline Barley & 45.9 & - \\
\hline Wheat & 34.7 & - \\
\hline Oat & - & 9.9 \\
\hline Sugar beet pulp & - & 70.8 \\
\hline Soybean meal & 5.0 & 4.9 \\
\hline Rapeseed meal & 4.1 & 5.0 \\
\hline Fish meal & 4.2 & 4.1 \\
\hline Molasses & 2.6 & 2.6 \\
\hline Urea & - & 0.4 \\
\hline Ammonia chloride & 1.1 & 1.1 \\
\hline Calcium carbonate & 2.3 & - \\
\hline Sodium dihydrogen phosphate & - & 1.1 \\
\hline \multicolumn{3}{|l|}{ Chemical composition (\% DM) } \\
\hline Ash & 6.0 & 8.9 \\
\hline Crude protein & 22.7 & 20.5 \\
\hline Crude fibre & 4.8 & 17.7 \\
\hline Ether extract & 2.5 & 2.1 \\
\hline $\mathrm{NDF}$ & 17.3 & 42.6 \\
\hline $\mathrm{ADF}$ & 6.5 & 19.9 \\
\hline $\mathrm{ADL}$ & 1.6 & 2.0 \\
\hline $\begin{array}{l}\text { Metabolisable energy (Mcal } \\
\text { per kg DM) }{ }^{\mathrm{a}}\end{array}$ & 2.96 & 2.68 \\
\hline PDIN $(g \text { per kg DM })^{b}$ & 131 & 125 \\
\hline PDIE $\left(g\right.$ per kg DM) ${ }^{b}$ & 129 & 129 \\
\hline
\end{tabular}

a Calculated from chemical analyses [20].

${ }^{\mathrm{b}}$ Calculated from tables of feed values [21].

weaned. From weaning to the beginning of the trial, all the lambs were offered the same commercial pelleted diet and meadow hay without restriction. At $53( \pm 5)$ days of age, they were individually penned on a slatted floor. Two groups of animals of similar average age, liveweight and sire origin were established as described by Normand et al. [35]. The lambs had free access to a second cut meadow hay and either a cereal based(group C) or a sugar beet pulp based (group P) pelleted concentrate feed. The composition and the nutritional values of these concentrates are presented in Table I. The lambs were slaughtered at $41.0( \pm 1.2) \mathrm{kg}$ live weight.

\subsection{Samplings and measurements}

The measurements of feed intake, average daily gain, plasma concentrations of metabolites as well as the measurements of the fattening status were presented by Normand et al. [35]. The softness (SI) of subcutaneous fat was judged on the chilled carcass according to the 5-point scale of Legrand [23] (1: very firm fat to 5: very soft and oily fat).

Immediately after slaughter, the adipose tissue (AT) was sampled at the base of the tail, then frozen into liquid nitrogen and stored at $-30{ }^{\circ} \mathrm{C}$ until analysis.

\subsection{Chemical analyses}

The water content of AT was measured after at least $48 \mathrm{~h}$ of freeze-drying. The lipids of AT were extracted according to an adaptation [8] of the method of Folch et al. [18].

The FA were transmethylated in the presence of $\mathrm{BF}_{3}$ and separated by gas chromatography, on a Varian $3400 \mathrm{CX}$, fitted with a flame ionisation detector and a DBWAX column $(\mathrm{L}=60 \mathrm{~m} ; \varnothing=0.25 \mathrm{~mm}$; $\mathrm{e}=0.25 \mu \mathrm{m}$; J\&W Scientific). After injection, the temperature of the column was increased from 60 to $120{ }^{\circ} \mathrm{C}$ (hold time $0.01 \mathrm{~min})$ at $10{ }^{\circ} \mathrm{C}$ per $\mathrm{min}$, then from $120{ }^{\circ} \mathrm{C}$ to $190{ }^{\circ} \mathrm{C}$ (hold time $50 \mathrm{~min}$ ) at $3{ }^{\circ} \mathrm{C}$ per min, and from $190{ }^{\circ} \mathrm{C}$ to $210^{\circ} \mathrm{C}$ (hold time $20 \mathrm{~min}$ ) at $10^{\circ} \mathrm{C}$ per min. The injector and detector temperatures were $250^{\circ} \mathrm{C}$ and $280{ }^{\circ} \mathrm{C}$, respectively. Helium was used as the carrier gas (flow $0.9 \mathrm{~mL}$ per min), with the split being closed only during the first minute after injection. The calculation of the area under the peak was done using the software Varian Star [44] with a low threshold $(0.02 \%$ of total FA). The results are expressed as the percentage of the considered methyl ester divided by the sum of all 
the methyl esters between $\mathrm{C}_{10: 0}$ and $\mathrm{C}_{20: 4}$. The FA were further identified from the equivalent chain-length (ECL) [29] determined by interpolation between two consecutive even straight-chain saturated FA and compared by reference to standards (Sigma, St. Louis, MO; Interchim, Montluçon, France) analysed under similar conditions and from mass spectra obtained by electron-impact. According to the structure, the FA were summed up by families (even straight-chain saturated FA, ESFA: $\mathrm{C}_{10: 0}+\mathrm{C}_{12: 0}+\mathrm{C}_{14: 0}+$ $\mathrm{C}_{16: 0}+\mathrm{C}_{18: 0}+\mathrm{C}_{20: 0}$; even straight-chain monounsatutated FA, EMUFA: $\mathrm{C}_{14: 1}+$ $\Sigma \mathrm{C}_{16: 1}+\Sigma \mathrm{C}_{18: 1}$; oddMUFA $=\mathrm{C}_{17: 1 n-8}+$ $\mathrm{C}_{19: 1} ; \mathrm{PUFA}=\mathrm{C}_{18: 2 \mathrm{n}-6}+\mathrm{C}_{18: 3 \mathrm{n}-3}+\mathrm{C}_{20: 4 \mathrm{n}-6}$ +4 isomers of linoleic acid (ECL: 18.71, 18.73, 18.76, 18.84), oddFA: $\mathrm{C}_{13: 0}+\mathrm{C}_{15: 0}+$ $\mathrm{C}_{17: 0}+\mathrm{C}_{17: 1}+\mathrm{C}_{19: 0}+\mathrm{C}_{19: 1}$; iso $\mathrm{FA}$ : iso $\mathrm{C}_{13: 0}+$ iso $\mathrm{C}_{14: 0}+$ iso $\mathrm{C}_{15: 0}+$ iso $\mathrm{C}_{16: 0}+$ iso $\mathrm{C}_{17: 0}+$ iso $\mathrm{C}_{18: 0}$; anteiso $\mathrm{FA}$ : anteiso $\mathrm{C}_{15: 0}+$ anteiso $\mathrm{C}_{17: 0}$; other saturated branched-chain FA (oBCFA): 4-methylFA + 6-methylFA, + 8-methylFA + 10-methylFA + 12-methylFA + polymethyl FA). IsoFA, anteisoFA and oBCFA represented, all together, the total branched FA (tBCFA). Rumenic acid was hardly detected and not quantified.

\subsection{Statistical analyses}

Data were analysed by variance-covariance analysis according to the Mixed procedure for an unbalanced design of SAS [40]. In the model, the type of concentrate was used as a fixed factor. The paternal origin and the interaction, paternal origin $x$ type of concentrate, were used as random factors with the lamb weight at the beginning of the experiment as a covariate. The relationships between the growth and feeding data and the FA composition of the caudal AT were studied using principal component analysis (PCA) and correlation within diet analysis [28]. Classification of the lambs was made by the DISCRIM procedure of SAS [40].

\section{RESULTS}

The paternal origin and the interaction paternal origin $\times$ type of concentrate had no significant effect on the growth and feeding data as well as on the FA composition of AT. Therefore, they will not be mentioned any longer in the present text.

\subsection{Feeding and growth}

The feed intake, the average daily liveweight gain, the plasma concentrations of the different metabolites measured and the carcass quality of the lambs were previously published by Normand et al. [35]. They are summarised in Table II. The metabolisable energy intake and the average daily liveweight gain were not significantly different between the two groups during the fattening period (overall means, 3.3 Mcal per $\mathrm{d}$ and $309 \mathrm{~g}$ per $\mathrm{d}$, respectively). Moreover, fat softness was not significantly different between the $\mathrm{C}$ and $\mathrm{P}$ groups $(P>0.10)$

\subsection{Water and lipid content}

Water and lipid content of the caudal AT are presented in Table III. No significant difference in the water and lipid content was observed between the $\mathrm{C}$ and $\mathrm{P}$ groups.

\subsection{Fatty acid composition}

The sum of the three major FA $\left(\mathrm{C}_{16: 0}\right.$, $\mathrm{C}_{18: 0}$ and cis $\left.\mathrm{C}_{18: 1 n-9}\right)$, ranged altogether from 48.9 to $73.6 \%$. The proportions of oddFA and $\mathrm{tBCFA}$ were $7.7 \pm 0.30(\mathrm{~min}=$ $3.6, \max =13.4 \%)$ and $8.9 \pm 0.46 \%(\mathrm{~min}=$ $3.5, \max =17.3 \%$ ), respectively. Together, they achieved a maximum of $29.9 \%$. The coefficients of variation were the lowest for EMUFA than for other families of FA (CV: 5.4, 18.0, 25.3, 27.3, 36.5\%, for EMUFA, ESFA, PUFA, oddFA, and tBCFA, respectively). The C-lambs had significantly lower percentages of ESFA and higher percentages of EMUFA, oddMUFA and PUFA than the P lambs (Tab. III). The difference between the groups in ESFA percentages 
Table II. Effect of the type of concentrate on performances, plasma concentrations of metabolites and carcass quality.

\begin{tabular}{|c|c|c|c|c|}
\hline & \multirow{2}{*}{$\begin{array}{c}\text { Cereals } \\
(\mathrm{n}=25) \\
\end{array}$} & \multicolumn{2}{|c|}{ Beet pulp } & \multirow[b]{2}{*}{$P$} \\
\hline & & $(\mathrm{n}=24)$ & $\mathrm{RSD}^{\mathrm{a}}$ & \\
\hline Adjusted $\mathrm{ADG}^{\mathrm{b}}$ (g per d) & 305 & 312 & 40 & NS \\
\hline DM intake (kg per d) & 1.12 & 1.26 & 0.10 & $<0.01$ \\
\hline Hay (\% DM intake) & 18.5 & 17.0 & 2.6 & NS \\
\hline MEI (kcal per $\mathrm{LW}^{0.75}$ ) & 247 & 236 & 20.8 & $=0.08$ \\
\hline Initial LW (kg) & 20.9 & 20.8 & NA & NA \\
\hline LW at slaughter $(\mathrm{kg})$ & 41.3 & 40.7 & 1.9 & NS \\
\hline Duration of the experiment (d) & 57.7 & 62.4 & 14.7 & NS \\
\hline Feed conversion ratio (kg DM per kg gain) & 3.72 & 4.10 & 0.38 & $<0.05$ \\
\hline Glucose (g per L) & 0.84 & 0.86 & 0.04 & NS \\
\hline Insulin (mU per L) & 19 & 19 & 4 & NS \\
\hline Non esterified fatty acids ( $\mu$ eq per L) & 68 & 62 & 26 & NS \\
\hline$\beta$-hydroxybutyrate (mg per L) & 28 & 41 & 9 & $<0.01$ \\
\hline Methylmalonate ( $\mu$ mol per $\mathrm{L}$ ) & 2.8 & 1.9 & 1.5 & $=0.09$ \\
\hline Cold carcass weight (kg) & 18.4 & 18.8 & 0.9 & NS \\
\hline Dorsal fat thickness (mm) & 4.6 & 4.4 & 1.1 & NS \\
\hline Subcutaneous fat softness index & 3.2 & 3.0 & 0.8 & NS \\
\hline Subcutaneous fat colour score & 3.2 & 3.1 & 0.9 & NS \\
\hline
\end{tabular}

The data presented are least-squares means.

${ }^{a}$ RSD: residual standard deviation. ${ }^{b}$ ADG adjusted by linear regression of the individual growth curve. NS: not significant $(P>0.10)$; NA $=$ not applicable.

resulted from a decrease in each long-chain FA percentage $\left(\mathrm{C}_{16: 0}, \mathrm{C}_{18: 0}\right.$ and $\left.\mathrm{C}_{20: 0}\right)$. For the $\mathrm{C}$-lambs the higher EMUFA percentage concerned $\mathrm{C}_{17: 1 n-8}$ and more particularly the isomers of oleic acid except $\mathrm{C}_{18: 1 n-9}$ $\left(\mathrm{oC}_{18: 1}\right)$, but not oleic $\left(\mathrm{C}_{18: 1 n-9}\right)$ and palmitoleic acid. The increase in PUFA percentage in the $\mathrm{C}$-lambs concerned each identified PUFA $\left(\mathrm{C}_{18: 2 n-6}, \mathrm{C}_{18: 3 n-3}, \mathrm{C}_{20: 4 n-6}\right)$. It also concerned the four FA eluting between $\mathrm{C}_{18: 2 n-6}$ and $\mathrm{C}_{19: 0}$ (ECL: 18.71, 18.73, 18.76 , and 18.84) which were probably isomers of linoleic acid, except conjugated linoleic acid isomers. There was no difference, between the groups, for the odd saturated FA. Each branched-chain FA (isoFA, anteisoFA, oBCFA) family appeared slighty higher in $\mathrm{P}$ - than in $\mathrm{C}$-lambs but none of these differences was significant between the two groups of lambs except a trend for isoFA. This difference in FA proportion between-group was significant for isoFA $(P<0.05)$ when the groups were compared to the same slaughter weight.

\subsection{Relationships between intake and lamb growth performance and FA composition of caudal adipose tissue}

Lamb weight at the beginning of the experiment (ILW) was positively related to the proportions of shorter-chain ESFA $(\mathrm{r}=$ $0.69, P<0.001 ; \mathrm{r}=0.66, P<0.001$; and $\mathrm{r}=0.25, P=0.08$, for $\mathrm{C}_{12: 0}, \mathrm{C}_{14: 0}$ and $\mathrm{C}_{16: 0}$; respectively). Likewise, it was positively related to $\mathrm{C}_{16: 1 n-9}$ and to $\mathrm{C}_{18: 1 n-9}(\mathrm{r}=0.54$, 
Table III. Effect of the type of concentrate on water and lipid content and fatty acid composition of caudal adipose tissue.

\begin{tabular}{|c|c|c|c|c|}
\hline & Cereals & Beet pulp & $\mathrm{RSD}^{\mathrm{j}}$ & $P$ \\
\hline & $\mathrm{n}=25$ & $\mathrm{n}=24$ & & \\
\hline Water \% & 24.1 & 21.6 & 5.3 & NS \\
\hline $\begin{array}{l}\text { Lipids (\% } \\
\text { wet weight) }\end{array}$ & 69.5 & 71.9 & 6.4 & NS \\
\hline $\mathrm{C}_{14: 0}$ & 3.6 & 3.1 & 1.2 & NS \\
\hline $\mathrm{C}_{15: 0}$ & 1.2 & 1.3 & 0.4 & NS \\
\hline $\mathrm{C}_{16: 0}$ & 19.3 & 21.4 & 3.1 & 0.02 \\
\hline $\mathrm{C}_{17: 0}$ & 3.4 & 3.2 & 0.73 & NS \\
\hline $\mathrm{C}_{18: 0}$ & 7.8 & 8.9 & 2.3 & 0.10 \\
\hline $\mathrm{C}_{20: 0}$ & 0.06 & 0.08 & 0.02 & 0.001 \\
\hline C16:1n-9 & 0.27 & 0.29 & 0.06 & NS \\
\hline C16:1n-7 & 2.9 & 3.0 & 0.44 & NS \\
\hline $\mathrm{C}_{17: 1 n-8}$ & 2.8 & 2.2 & 0.97 & 0.04 \\
\hline $\mathrm{C}_{18: 1 n-9}$ & 34.4 & 33.8 & 3.1 & NS \\
\hline $\mathrm{oC}_{18: 1}$ & 9.2 & 6.8 & 2.1 & 0.001 \\
\hline $\mathrm{C}_{18: 2 n-6}$ & 3.2 & 2.2 & 0.53 & 0.001 \\
\hline $\mathrm{C}_{18: 3 n-3}$ & 0.65 & 0.48 & 0.16 & 0.001 \\
\hline isoFA ${ }^{\mathrm{a}}$ & 1.4 & 1.5 & 0.20 & 0.07 \\
\hline anteiso $\mathrm{FA}^{\mathrm{b}}$ & 1.5 & 1.6 & 0.33 & NS \\
\hline oddSFA $^{c}$ & 4.8 & 4.7 & 1.1 & NS \\
\hline oddMUFA $^{\mathrm{d}}$ & 3.3 & 2.6 & 1.2 & 0.04 \\
\hline $\mathrm{oBCFA}^{\mathrm{e}}$ & 5.6 & 6.3 & 3.0 & NS \\
\hline $\mathrm{tBCFA}^{\mathrm{f}}$ & 8.5 & 9.4 & 3.3 & NS \\
\hline ESFAg $^{g}$ & 30.6 & 34.4 & 5.6 & 0.02 \\
\hline EMUFA $^{\mathrm{h}}$ & 47.2 & 44.5 & 2.1 & 0.001 \\
\hline PUFA $^{\mathrm{i}}$ & 4.7 & 3.4 & 0.80 & 0.001 \\
\hline
\end{tabular}

The data presented are least-squares means. NS: not significant $(P>0.10)$.

a isoFA: sum of FA of iso structure.

$\mathrm{b}$ anteisoFA: sum of FA of anteiso structure.

${ }^{c}$ oddSFA: odd saturated FA.

d oddMUFA: odd unsaturated FA.

e oBCFA: branched-chain FA other than those of iso and anteiso structure.

f tBCFA: total branched-chain FA.

g ESFA: even saturated FA.

$\mathrm{h}$ EMUFA: even monounsaturated FA.

i PUFA: polyunsaturated FA.

j RSD: residual standard deviation.

$P<0.001$, and $\mathrm{r}=0.52, P<0.001$, respectively) and negatively to $\mathrm{oC}_{18: 1}(\mathrm{r}=-0.37$, $P<0.01)$ but not significantly related to $\mathrm{C}_{16: 1 n-7}$. Initial liveweight (ILW) was negatively related to oddFA, anteisoFA, and
oBCFA (r $=-0.39, P<0.01 ; \mathrm{r}=-0.30$, $P<0.05, \mathrm{r}=-0.38, P<0.01$, respectively). Growth rate had no effect on FA percentages. The level of energy intake was positively associated with oddFA $(P<0.05)$, particularly with $\mathrm{C}_{17: 0}(P<0.01)$ and negatively with total ESFA $(P=0.06)$, particularly with $\mathrm{C}_{18: 0}(P<0.05)$.

Principal component analysis (PCA) was performed to examine the relationships between most of the FA and the softness index (SI), the water content of AT (AT\% water), ILW, average level of energy intake (kcal per kg LW ${ }^{0.75}, \mathrm{MEI}$ ), average daily gain (ADG), percentage of hay in the daily ration (hay ratio), and duration of the experiment (DEX), (Fig. 1a, b). The chosen parameters were the ones that presented the largest within-group variability. The 4 first axes of the PCA explained $71.6 \%$ of the total variance $(33.0,18.2,11.4$, and $9.0 \%$, respectively). The first principal component (PC) showed an antagonism between oddFA, oBCFA, anteisoFA, $\mathrm{C}_{16: 1 n-7}, \mathrm{AT} \%$ water and SI on the one hand and $\mathrm{C}_{12: 0}$, $\mathrm{C}_{14: 0}, \mathrm{C}_{18: 0}, \mathrm{C}_{16: 0}, \mathrm{C}_{16: 1 n-9}$, ILW, on the other hand (Fig. 1a). Besides, PC two showed an antagonism between $\mathrm{oC}_{18: 1}$, $\mathrm{C}_{18: 2 n-6}, \mathrm{C}_{18: 3 n-3}$ and DEX on the one hand and $\mathrm{C}_{18}: 1 n-9$, ILW, and ADG on the other hand. The fatty acids were less discriminated on PC 3 and 4 than on the two first ones. On $\mathrm{PC}$ three, hay ratio, $\mathrm{DEX}$ and $\mathrm{C}_{18: 0}$ seemed opposed to ADG, MEI, $\mathrm{C}_{18: 2 n-6}$ and $\mathrm{C}_{18: 3 n-3}$, while $\mathrm{C}_{18: 1 n-9}, \mathrm{C}_{18: 0}, \mathrm{C}_{16: 1 n-9}$, SI and ADG seemed opposed to DEX and $\mathrm{C}_{16: 1 n-7}$, on PC four (Fig. 1b). Principal components 1, 3 and 4 did not discriminate between $\mathrm{C}$ and $\mathrm{P}$ lambs. PC 2 was significantly lower for $\mathrm{C}$ - than P-lambs $(-0.46 \pm$ 0.22 vs. $0.48 \pm 0.12, P<0.001)$. Nevertheless, when discriminant analysis with all FA or groups of FA used in the factor analysis was performed, almost all the lambs could be classified in their respective group (100\% and $96 \%$, for P-and C-lambs, respectively).

The relationships between lamb performance and FA composition of the caudal adipose tissue could be different between 

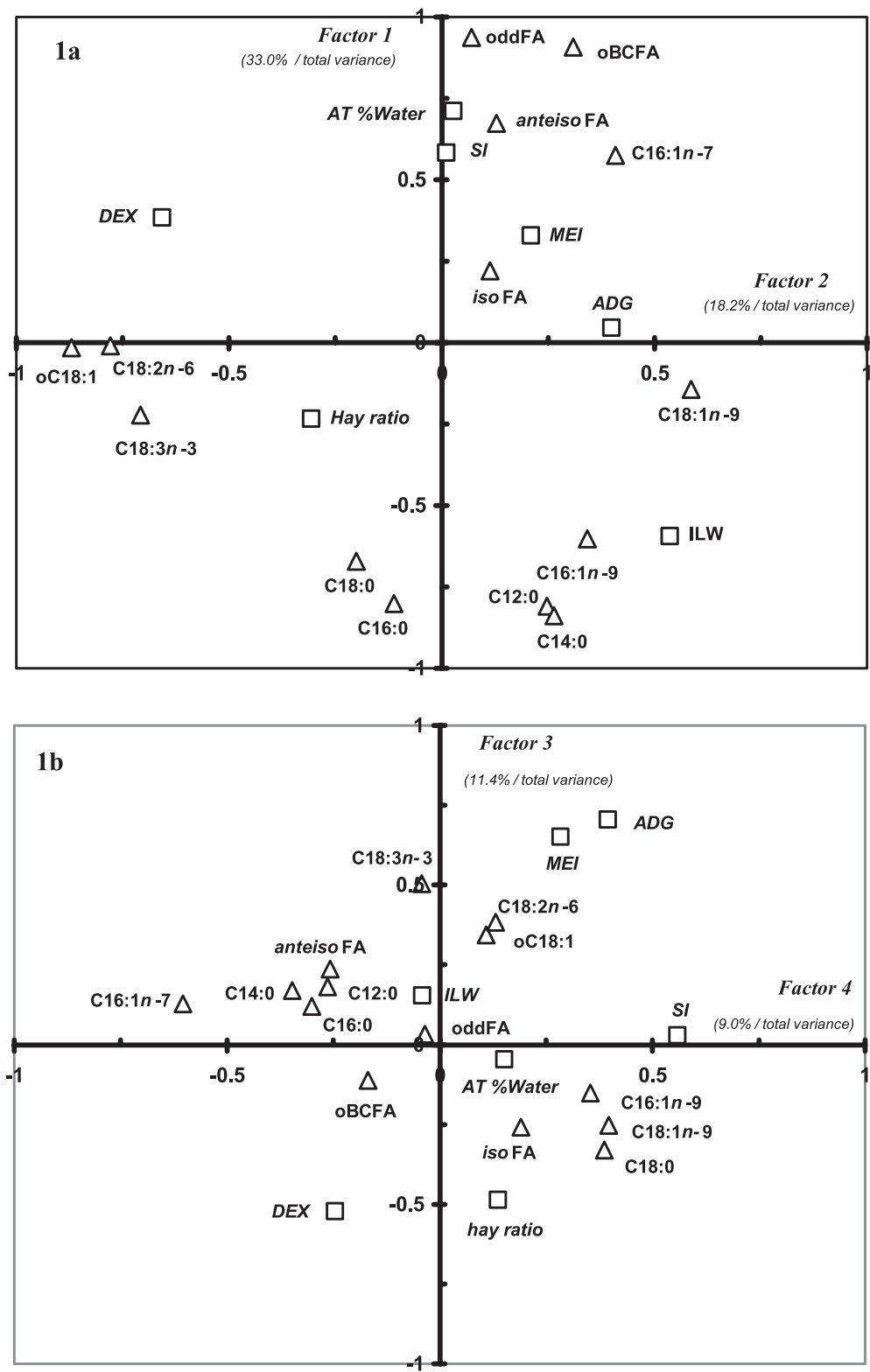

Figure 1. Principal component analysis loadings between fatty acid percentages and softness index (SI), water content of AT (AT\% water) and initial live weight (ILW), average level of energy intake, kcal per kg LW 0.75 (MEI), average daily gain (ADG), percentage of hay in the daily ration (hay ratio), and duration of the experiment (DEX). 
Table IV. Coefficients of correlation between water content, lipid content and fatty acid composition of caudal adipose tissue and growth performances of lambs fed the cereal-based diet or the beet pulpbased diet.

Water Lipids ESFA EMUFA oddSFA oddMUFA PUFA isoFA anteisoFA oBCFA tBCFA $(\%) \quad(\%)$

\begin{tabular}{|c|c|c|c|c|c|c|c|c|c|c|c|}
\hline \multicolumn{12}{|l|}{ Cereal-based diet ${ }^{a}$} \\
\hline Initial live weight & -0.46 & -0.44 & 0.20 & 0.39 & -0.41 & -0.17 & -0.34 & -0.46 & -0.16 & -0.22 & -0.23 \\
\hline $\operatorname{MEI}(\mathrm{kcal} \cdot \mathrm{kg} \mathrm{LW}-0.75)$ & 0.25 & -0.34 & -0.55 & 0.08 & 0.62 & 0.47 & 0.16 & 0.02 & $\mathbf{0 . 5 0}$ & 0.44 & 0.45 \\
\hline $\operatorname{ADG}\left(g \cdot d^{-1}\right)^{b}$ & 0.18 & -0.24 & -0.33 & 0.21 & 0.31 & 0.24 & 0.13 & 0.04 & 0.33 & 0.20 & 0.22 \\
\hline Hay ratio & -0.17 & 0.27 & 0.55 & -0.23 & -0.51 & -0.53 & -0.22 & 0.15 & -0.42 & -0.37 & -0.39 \\
\hline Age at slaughter & 0.07 & 0.06 & 0.03 & 0.27 & 0.05 & -0.02 & 0.16 & 0.18 & 0.02 & 0.02 & 0.04 \\
\hline Softness index & 0.57 & -0.54 & -0.53 & 0.08 & 0.63 & 0.45 & -0.03 & 0.16 & 0.20 & 0.46 & 0.45 \\
\hline Glucose & 0.22 & -0.19 & -0.06 & -0.26 & 0.10 & 0.13 & 0.52 & 0.17 & 0.28 & 0.01 & 0.04 \\
\hline Insulin & -0.32 & 0.25 & -0.17 & 0.18 & 0.16 & 0.11 & -0.06 & -0.28 & 0.21 & 0.13 & 0.13 \\
\hline BHB & -0.13 & 0.21 & 0.39 & -0.14 & -0.42 & -0.34 & -0.50 & -0.07 & -0.46 & -0.19 & -0.22 \\
\hline Methylmalonate & -0.20 & 0.22 & 0.14 & 0.29 & -0.29 & -0.20 & -0.02 & -0.24 & -0.08 & -0.20 & -0.20 \\
\hline \multicolumn{12}{|c|}{ Beet pulp-based diet $t^{a}$} \\
\hline Initial live weight & -0.12 & 0.19 & 0.40 & 0.43 & -0.48 & 0.39 & 0.19 & -0.25 & -0.48 & -0.53 & -0.53 \\
\hline $\operatorname{MEI}(\mathrm{kcal} \cdot \mathrm{kg} \mathrm{LW}-0.75)$ & -0.18 & 0.18 & 0.03 & -0.14 & 0.21 & -0.12 & 0.12 & -0.11 & -0.01 & -0.03 & -0.03 \\
\hline $\operatorname{ADG}\left(\mathrm{g} \cdot \mathrm{d}^{-1}\right)^{\mathrm{b}}$ & 0.08 & -0.02 & 0.17 & 0.27 & -0.23 & -0.25 & 0.03 & -0.06 & -0.04 & -0.29 & -0.27 \\
\hline Hay ratio & -0.09 & 0.18 & -0.14 & -0.16 & 0.26 & 0.13 & 0.03 & 0.06 & 0.30 & 0.13 & 0.15 \\
\hline Age at slaughter & -0.02 & -0.03 & -0.36 & -0.35 & 0.44 & 0.37 & -0.18 & 0.25 & 0.32 & 0.47 & 0.47 \\
\hline Softness index & 0.43 & -0.43 & -0.43 & -0.13 & 0.50 & 0.33 & -0.34 & 0.33 & 0.30 & 0.44 & 0.44 \\
\hline Glucose & -0.27 & 0.16 & -0.28 & -0.21 & 0.12 & 0.06 & 0.10 & 0.16 & 0.03 & 0.08 & 0.08 \\
\hline Insulin & -0.39 & 0.39 & -0.04 & 0.01 & 0.11 & 0.01 & 0.14 & 0.15 & -0.09 & -0.01 & -0.01 \\
\hline BHB & 0.44 & -0.44 & -0.45 & -0.13 & 0.40 & 0.44 & -0.43 & -0.16 & 0.34 & 0.51 & 0.48 \\
\hline Methylmalonate & -0.30 & 0.40 & 0.36 & 0.47 & -0.45 & -0.42 & 0.10 & -0.04 & -0.19 & -0.54 & -0.50 \\
\hline
\end{tabular}

a $n=25$, for the cereal-based diet and $n=24$, for the beet pulp-based diet.

$\mathrm{b}$ ADG adjusted by linear regression of the individual growth curve.

Data in bold are significant at $P<0.05$.

the two diets (Tab. IV). For the C-lambs, the mean metabolisable energy intake per unit of metabolic weight was positively correlated with the proportion of saturated $\operatorname{oddFA}(r=0.61)$ and BCFA $(r=0.43)$, and negatively correlated with $\operatorname{ESFA}(\mathrm{r}=-0.53)$. Moreover, the percentage of hay was correlated with the saturated even and oddFA $(r=0.55$ and $r=-0.51$, respectively) in the $\mathrm{C}$ group. On the contrary, in the $\mathrm{P}$ group, the plasma concentrations of $\beta$-hydroxybutyrate (BHB) and methylmalonate (MMA) were correlated with the proportion of saturated oddFA and total BCFA (respectively, $\mathrm{r}=$ 0.40 and $r=0.48$, for $\mathrm{BHB} ; \mathrm{r}=-0.45$ and $r=-0.50$ for MMA).

\section{DISCUSSION}

The results of feed intake, growth rate, plasma concentration of metabolites, ruminal fermentation and carcass quality were discussed previously by Normand et al. [35]. 

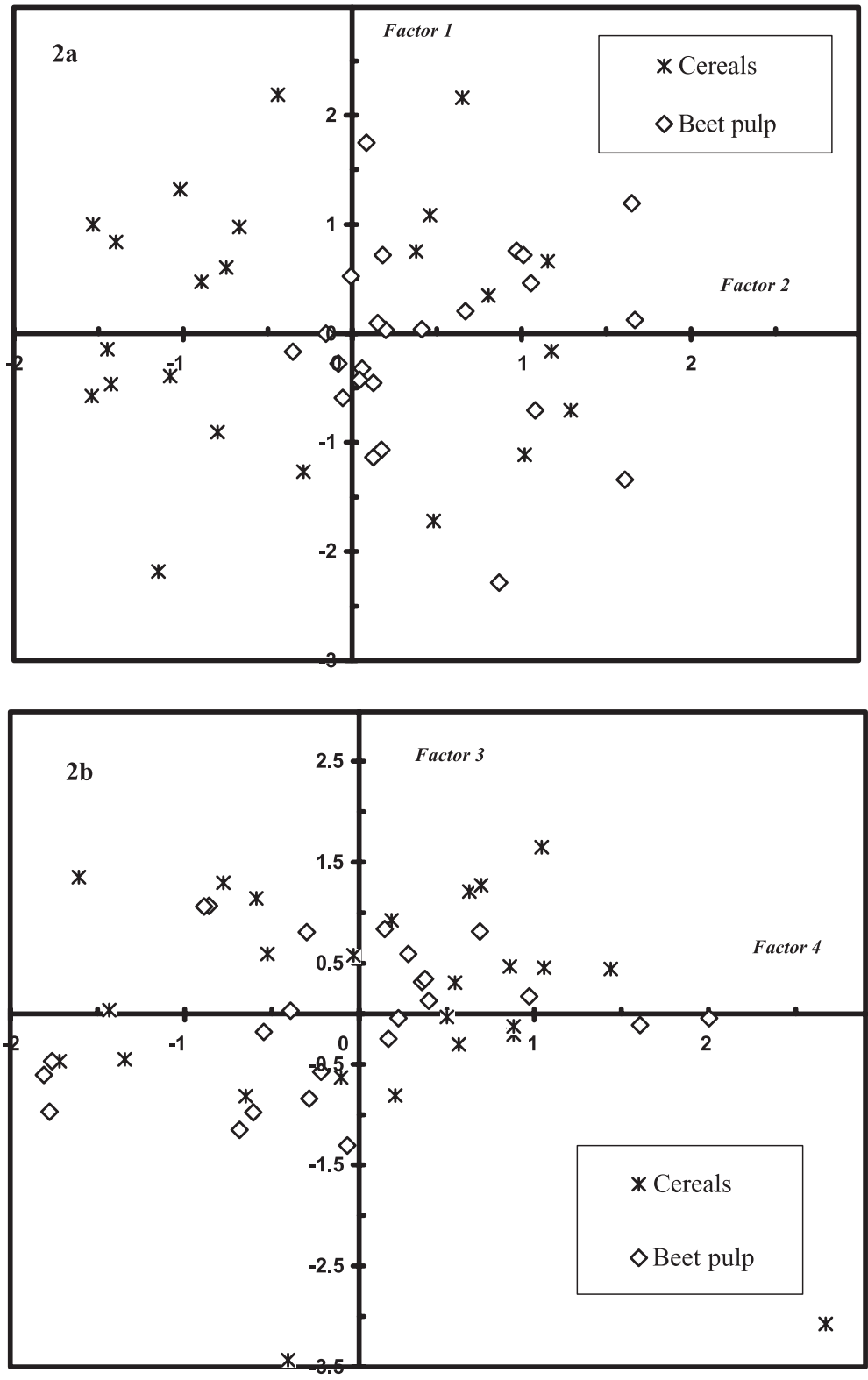

Figure 2. Lamb score in the first two factor axes of the principal component analysis performed with fatty acid percentages and softness index, water content of adipose tissue, initial live weight, level of intake and growth performance. 


\subsection{Fat softness}

The first axis of the PCA corresponded with the degree of fat softness. Softness was associated with adipose tissue water content and proportions of oddFA and oBCFA and anteisoFA, but was the opposite to ESFA $\left(\mathrm{C}_{12: 0}, \mathrm{C}_{14: 0}, \mathrm{C}_{16: 0}\right.$ and $\left.\mathrm{C}_{18: 0}\right)$, as reported by Bas et al. [9] and Bozzolo and BouillierOudot [12]. These relationships confirmed the conclusions of several authors who related the fat softness problem to high adipose tissue water content $[4,30]$ and high proportions of oddFA and BCFA $[9,27$, 36]. The relationship between SI and BCFA appeared closer with oBCFA than anteisoFA and not with isoFA, which is probably a consequence of the origin of these groups of FA. The iso and anteisoFA are synthesised by rumen bacteria from branched amino acids: from valine and leucine for the iso $\mathrm{FA}$ and from isoleucine for the anteiso $\mathrm{FA}$ $[3,15]$. However, the anteisoFA can also be synthesised de novo from propionate by incorporation of methylmalonyl-CoA instead of malonyl-CoA during the synthesis of these FA. The other methyl-branched chain FA are supposed to be only of endogenous origin [41].

In this study, the mean water content of the caudal adipose tissue was quite high and of similar level compared to the results obtained by Bozzolo et al. [13] and Bas et al. [9] on lambs of the same genetic type having soft subcutaneous adipose tissue. Moreover, the proportions of oddFA and BCFA were among the highest levels found in the literature even though they were from caudal AT which is known to have lower oddFA and BCFA contents than back AT as shown by Bas et al. [9]. These data were quite similar to those obtained by Bas et al. [9] on soft caudal AT and by Garton et al. [19] on dorsal AT of lambs fed a propionate supplemented diet. In turn, the proportion of ESFA was lower than the data from the literature. This low level was mainly due to the $\mathrm{C}_{18: 0}$ proportion which was $2,3.5$, and 7 points below mean values reported by Garton et al. [19], Berthelot et al. [10] and
Bas and Morand-Fehr [7], respectively. Finally, the composition of caudal AT corresponded to soft AT as suggested by the SI values.

The unsaturated FA with 18 atoms of carbon are usually related to AT softness by decreasing the AT melting point [7, 17, 24]. However, in this study, they were not linked to fat softness. This might be due to the low proportion of $\mathrm{C}_{18: 2}$ which was 1 to 2 points lower than the proportion reported by Bas and Morand-Fehr [7], Berthelot et al. [10] and Garton et al. [19] and to the high proportions of oddFA and BCFA as reported by Bas et al. [9].

The mean metabolisable energy intake per unit of metabolic weight was related to the soft fat. This confirmed the effect of the quantity of energy intake in the occurrence of soft adipose tissue as reported by Busboom et al. [14]. However, surprisingly, the growth rate did not influence fat softness although growth rate was closely linked to MEI. This is contrary to the results of Bozzolo et al. [13] who showed that growth rates were positively correlated with fat softness. On the contrary, the weight and age at the beginning of the experiment which are good indicators of the weight and age of the animals at the weaning period were associated to ESFA such as $C_{10: 0}$, $\mathrm{C}_{12: 0}, \mathrm{C}_{14: 0}$ and $\mathrm{C}_{16: 0}$ present in high proportions in ewe milk. The heavier and more mature lambs at the beginning of the experiment may have stored higher contents of medium chain FA, and deposited less FA during the experimental period with a shorter fattening period. Moreover, the storage of medium chain FA during the suckling period has been reported to have a positive effect on fat softness [5, 39].

\subsection{Dietary effects}

Fat softness, water content and the proportions of $\mathrm{C}_{10: 0}, \mathrm{C}_{12: 0}$, and $\mathrm{C}_{14: 0}$, of oddFA, anteisoFA and $\mathrm{oBCFA}$ were not different between the 2 diets. Therefore, the lambs fed the cereal-based diet were not separated 
from those fed the beet pulp-based diet according to the first axis of the PCA. No difference in the proportion of FA synthesised via the propionate pathway was shown between the two diets. We therefore questioned the initial hypothesis of the effect of the type of concentrates on fat softness. However, the relationships between the quantity of energy intake and the proportions of oddFA and BCFA were different according to the type of concentrate. The metabolisable energy intake per unit of metabolic weight was positively correlated with these FA for the lambs fed the cerealbased diet whereas no relationship was observed for the lambs fed the beet pulpbased diet. There are two possible explanations: the quantity of nutrients or the balance between the nutrients.

For the cereal-based diet, two non-exclusive hypotheses exist. In this type of diet, there is usually greater ruminal production of propionate. This may lead to higher fluxes of propionate arriving to the liver and to a slight decrease in the hepatic extraction ratio of propionate. Therefore, peripheral tissues will be exposed to higher availability of propionate [11]. Even in the case of a stable hepatic extraction ratio of propionate, the quantity of propionate available for the synthesis of oddFA and BCFA might also be high due to the mass action law: more energy intake might lead to an increase in the propionate absorption rate and therefore to a higher quantity of propionate available for peripheral tissues and for the synthesis of oddFA or BCFA in AT.

In the beet pulp-based diet, ruminal production of propionate is often lower than with barley-based diets [25, 31, 43]. The quantity of propionate arriving to the liver may have been lower compared to the cereal-based diet. Moreover, ruminal concentration of butyrate is usually higher $[25$, $31,43]$, which led, in this study, to a higher plasma concentration of $\beta$-hydroxybutyrate in the $\mathrm{P}$ group than in the $\mathrm{C}$ group. In some studies [2,22], butyrate is thought to decrease the hepatic extraction ratio of propionate.
So, the quantity of propionate available for the synthesis of oddFA and BCFA might be increased and might be similar to that of the cereal-based diet. Moreover, the intake of beet pulp might lead to a higher availability of glucose in the organism, which could contribute to a slight decrease in the hepatic extraction ratio of propionate.

The second component represented an unsaturation of AT. It expressed an increase in the de novo synthesis of oleic acid when PUFA availability was reduced. The proximity of $\mathrm{oC}_{18: 1}$ and $\mathrm{C}_{18: 2 n-6}$ and $\mathrm{C}_{18: 3 n-3}$ expressed a common origin. The outflow of $\mathrm{oC}_{18: 1}$ was increased as the dietary forage level increased [6, 38]. These isomers of oleic acid were probably mainly transisomers originating from incomplete ruminal biohydrogenation of dietary linoleic and linolenic acid to stearic acid. PUFA are of exogenous origin: $C_{18: 3}$ may mainly arise from hay and soybean, rapeseed and fish meals, while $\mathrm{C}_{18.2}$ arises from wheat and barley [1, 32]. The higher proportions of $\mathrm{C}_{18: 2}$ and $\mathrm{C}_{18: 3}$ in AT in the C-group compared to the P-group may be due to a higher intake of the corresponding FA from the diet as expected from tables of composition of food materials [1] from which $\mathrm{C}_{18: 2}$ and $\mathrm{C}_{18: 3}$ appear 1.7 and 1.5 times higher in the $\mathrm{C}$-diet than in the P-diet. Moreover, to a lesser extent, hydrolysis and hydrogenation of dietary lipids may have been more complete in the rumen with the P-diet, as reflected by a higher stearic acid proportion and a lower proportion of isomers of oleic acid in P-than in C-lambs. This may result in steadier fermentations and a lower drop in ruminal $\mathrm{pH}$ with beet pulp based-diets than with cereal based-diets, as indicated by van Eenaeme et al. [43]. The increase in hydrolysis and biohydrogenation of dietary lipids with the beet pulp based-diet could result in an increase in the bacterial population or a shift towards bacteria that were consistent with the higher isoFA proportion in the adipose tissue [6]. ADG and MEI are best represented on axes 3 and 4 . These axes of the PCA were related to diet intake and growth performance. The greater energy 
intake resulted in the higher ADG and the lower hay ratio and the shorter duration of the experiment.

\section{CONCLUSIONS}

Substitution of cereals by sugar beet pulp in the lamb diet had no beneficial effect on the softness of subcutaneous adipose tissue and had no effect on the water content and on the proportion of oddFA or BCFA of caudal AT adipose tissue. The proportions of these FA reached high values associated with the soft adipose tissue problem observed in both diets. The hypothesis of a decrease in the proportions of FA synthesised from propionate via the type of concentrate was not supported by the results of this study. The beet pulp-based diet induced a decrease in the proportion of PUFA and in the proportion of the intermediate associated with hydrogenation of PUFA. However, no relationship was observed between these PUFA and the subcutaneous fat softness.

\section{ACKNOWLEDGEMENTS}

The authors wish to thank Annie Rouzeau for skilful technical assistance in the fatty acid analysis and the people of the experimental unit and slaughterhouse of Theix for taking good care of the animals during this experiment.

\section{REFERENCES}

[1] AFZ, IO-7 - la banque de données de l'alimentation animale, Association Française de Zootechnie, 2000

[2] Aiello R.J., Armentano L.E., Bertics S.J., Murphy A.T., Volatile fatty acid uptake and propionate metabolism in ruminant hepatocytes, J. Dairy Sci. 72 (1989) 942-949.

[3] Allison M.J., Bryant M.P., Katz I., Keeney M., Metabolic function of branched-chain volatile fatty acids, growth factors for ruminococci - II. Biosynthesis of higher branchedchain fatty acids and aldehydes, J. Bacteriol. 83 (1962) 1084-1093.
[4] Aurousseau B., Thériez M., Daniel M. Influence de la nature des matières grasses incorporées dans l'aliment d'allaitement sur le métabolisme lipidique de l'agneau de boucherie, Ann. Biol. Anim. Bioch. Biophys. 13 (1973) 93-105.

[5] Bas P., Croissance et métabolisme lipidique du ruminant autour du sevrage - Étude sur modèle caprin, thèse de l'INA P-G, 1993.

[6] Bas P., Archimède H., Rouzeau A., Sauvant D., Fatty acid composition of mixed-rumen bacteria: effect of concentration and type of forage, J. Dairy Sci. 86 (2003) 2940-2948.

[7] Bas P., Morand-Fehr P., Effect of nutritional factors on fatty acid composition of lamb fat deposits, Livest. Prod. Sci.64 (2000) 61-79.

[8] Bas P., Rouzeau A., Morand-Fehr P., The extraction of animal fats using the soxtec HT system, Focus 9 (1986) 10-11.

[9] Bas P., Giral B., Rouzeau A., Défauts de qualité des gras de couverture des agneaux de race Lacaune élevés en bergerie, in: Flamant J.C., Gabiña D., Espejo Diaz M. (Eds.), Proceedings of the International Symposium on basis of the quality of typical Mediterranean animal products, Badajoz, 29/09-02/10/1996, Wageningen Pers, Wageningen, EAAP Publication 90,1998 , pp. $451-455$.

[10] Berthelot V., Bas P., Schmidely P., DuvauxPonter C., Effect of dietary propionate on intake patterns and fatty acid composition of adipose tissues in lambs, Small Rumin. Res. 40 (2001) 29-39.

[11] Berthelot V., Pierzynowski S.G., Sauvant D., Kristensen N.B., Hepatic metabolism of propionate and methylmalonate in growing lambs, Livest. Prod. Sci. 74 (2001) 33-43.

[12] Bozzolo G., Bouillier-Oudot M., Composition en acides gras, fermeté et coloration du tissu adipeux sous-cutané des carcasses d'agneaux, Ann. Zootech. 48 (1999) 47-58.

[13] Bozzolo G., Bouillier-Oudot M., De Boisseson E., Ghassan E., Grasset D., Influence des performances zootechniques sur les caractéristiques des tissus adipeux d'agneaux de bergerie, sevrés précocement et alimentés avec un régime à forte concentration énergétique, Ann. Zootech. 39 (1990) 77-94.

[14] Busboom J.R., Miller G.J., Field R.A., Crouse J.D., Riley M.L., Nelms G.E., Ferrell C.L., Characteristics of fat from heavy ram and wether lambs, J. Anim. Sci. 52 (1981) 83-92.

[15] Duncan W.R.H., Garton G.A., Differences in the proportions of branched-chain fatty acids 
in subcutaneous triacylglycerols of barley-fed ruminants, Brit. J. Nutr. 40 (1978) 29-33.

[16] Duncan W.R.H., Orskov E.R., Garton G.A., Fatty acid composition of triglycerides of lambs fed on barley-based diets, Proc. Nutr. Soc. 31 (1972) 19A-20A.

[17] Field R.A., Rule D.C., Riley M.L., Characteristics of fat from heavy lambs fed a $90 \%$ corn diet or alfalfa pellets, Sheep Res. J. 8 (1992) 77-80.

[18] Folch J., Lees M., Sloane-Stanley C.H.S., A simple method for the isolation and purification of total lipids from animal tissues, J. Biol. Chem. 226 (1957) 497-509.

[19] Garton G.A., De B. Hovell F.D., Duncan W.R.H., Influence of dietary volatile fatty acids on the fatty-acid composition of lamb triglycerides, with special reference to the effect of propionate on the presence of branched-chain components, Brit. J. Nutr. 28 (1972) 409-416.

[20] Giger-Reverdin S., Aufrère J., Sauvant D., Demarquilly C., Vermorel M., Prediction of the energy values of compound feeds ruminants, Anim. Feed Sci. Technol. 48 (1994) 73-98.

[21] INRA - AFZ, Tables de composition et de valeur nutritive des matières premières destinées aux animaux d'élevage, in: Sauvant D. Perez J.M., Tran G. (Eds.), INRA Éditions, Paris, 2002.

[22] Krehbiel C.R., Harmon D.L., Schnieder J.E., Effect of increasing ruminal butyrate on portal and hepatic nutrient flux in steers, J. Anim. Sci. 70 (1992) 904-914.

[23] Legrand I., Dossier qualité du gras (1 ${ }^{\text {re }}$ partie), Pâtre 411 (1994) 21-31

[24] L’Estrange J.L., Mulvihill T.A., A survey of fat characteristics of lamb with particular reference to the soft fat condition in intensively fed lambs, J. Agr. Sci. Camb. 84 (1975) 281290.

[25] Mandebvu P., Galbraith H., Effect of sodium bicarbonate supplementation and variation in the proportion of barley and sugar beet pulp on growth performance and rumen, blood and carcass characteristics of young entire male lambs, Anim. Feed Sci. Technol. 82 (1999) 37-49.

[26] Matray M., Sagot L., Van Quackebeke E., Influence de la composition du régime d'engraissement sur la qualité des carcasses d'agneaux, Renc. Rech. Rum. 1 (1994) 205208.
[27] Miller G.J., Kunsman J.E., Field R.A., Characteristics of soft subcutaneous fat in ram lambs fed corn and corn-silage diets, J. Food Sci. 45 (1980) 279-282.

[28] Minitab, Reference manual, Minitab Inc., State College, PA, 1996.

[29] Miwa T.K., Mikolajzack K.L., Earle F.R., Wolff I.A., Gas chromatographic characterization of fatty acids - Identification of constants for mono and dicarboxylic methyl esters, Anal. Chem. 32 (1960) 1739-1742.

[30] Molénat G., Thériez M., Influence du mode d'élevage sur la qualité de carcasse de l'agneau de bergerie, Ann. Zootech. 22 (1973) 279-293.

[31] Moloney A.P., Growth and carcass composition in sheep offered isoenergetic rations which resulted in different concentrations of ruminal metabolites, Livest. Prod. Sci. 56 (1998) 157-164.

[32] Morand-Fehr P., Tran G., La fraction lipidique des aliments et les corps gras utilisés en alimentation animale, INRA Prod. Anim. 14 (2001) 285-302.

[33] Normand J., Bas P., Gouëdard A., Pottier E., Aurousseau B., Matray M., Thériez M., Sauvant D., Fermeté et composition des tissus adipeux sous-cutanés chez l'agneau de bergerie: effets du sexe, de l'alimentation et de l'origine paternelle, Renc. Rech. Rum. 4 (1997) 303306.

[34] Normand J., Thériez M., Bas P., Aurousseau B., Sauvant D., Effet de la nature de l'énergie ingérée, céréales vs. pulpes de betteraves, sur les performances de croissance et la qualité des carcasses d'agneaux de bergerie, Ann. Zootech. 48 (1999) 367-380.

[35] Normand J., Thériez M., Bas P., Berthelot V., Aurousseau B., Sauvant D., Effect of type of concentrate, cereals vs. sugar beet pulp, on rumen fermentation, plasma concentration of methylmalonate and quality of subcutaneous adipose tissue of intensively reared lambs, Anim. Res. 50 (2001) 275-288.

[36] Orskov E.R., Duncan W.R.H., Carnie C.A., Cereal processing and food utilization by sheep -3 . The effect of replacing whole barley by whole oats on food utilization and firmness and composition of subcutaneous fat, Anim. Prod. 21 (1975) 51-58.

[37] Pearce J., Chestnutt D.M.B., A comparison of the fatty acid composition of adipose tissue triglyceride from grass-fed and intensivelyreared lambs, Proc. Nutr. Soc. 33 (1974) 99A100A. 
[38] Sackmann J.R., Duckett S.K., Gillis M.H. Realini C.E., Parks A.H., Eggelston R.B., Effects of forage and sunflower oil levels on ruminal biohydrogenation of fatty acids and conjugated linoleic acid formation in beef steers fed finishing diets, J. Anim. Sci. 81 (2003) 3174-3181

[39] Sañudo C., Sierra I., Olleta J.L., Martin L., Campo M.M., Santolaria P., Wood J.D., Nute G.R., Influence of weaning on carcass quality, fatty acid composition and meat quality in intensive lamb production systems, Anim. Sci. 66 (1998) 175-187.

[40] SAS Institute Inc., SAS/STAT user's Guide, Version 6, 4th ed., SAS Institute Inc., Cary, NC, 1989.

[41] Scaife J.R., Wahle K.W.J., Garton G.A., Utilization of methylmalonate for the synthesis of branched-chain fatty acids by preparations of chicken liver and sheep adipose tissue, Biochem. J. 176 (1978) 799-804.

[42] Thériez M., Brun J.P., Utilisation des pulpes de betteraves déshydratées par l'agneau à l'engraissement, Bull. Tech. CRZV Theix 54 (1983) 27-30.

[43] Van Eenaeme C., Istasse L., Gabriel A., Clinquart A., Maghuin-Rogister G., Bienfait J.M., Effects of dietary carbohydrate composition on rumen fermentation, plasma hormones and metabolites in growing-fattening bulls, Anim. Prod. 50 (1990) 409-416.

[44] Varian, Star Chromatography Workstation, version 4.5, Varian Associates Inc., Palo Alto, CA, 1996. 